\title{
Effects of Dietary Calcium Levels and Limestone Particicle Size on The Performance, Tibia and Blood of Laying Hens
}

-Author(s)

Pelicia $\mathrm{K}^{1}$

Mourao JLM ${ }^{3}$

Garcia EA²

Pinheiro VMC ${ }^{3}$

Berto DA ${ }^{4}$

Molino $A B^{4}$

Faitarone $A B G^{4}$

Vercese $\mathrm{F}^{4}$

Santos GC

Silva $\mathrm{AP}^{4}$

Ph.D., Head Professor of the Department of Animal Science of the School of Agriculture and Animals Science of Universidade José do Rosário Vellano - UNIFENAS. Alfenas, MG, Brazil.

2 Ph.D., Head Professor of the Department of Animal Production, FMVZ/UNESP.Botucatu, SP, Brazil.

3 Ph.D., Head Professor CECAV, Dept. of Animal Sciences - Universidade do Trás-osMontes and Alto Douro (UTAD). Vila Real, Portugal.

4 Students of the Post-Graduation Program in Animal Science of FMVZ/UNESP.Botucatu, SP, Brazil.

\section{Mail Adress}

Kleber Pelícia

Rua Dr. João Candido Villas Boas, 351

Vila Pinheiro

18.609-690. Botucatu, SP, Brazil.

Tel: (14) 38825735 / 3811-7185

E-mail: fokleber@hotmail.with

\section{- Keywords}

Egg production, mineral nutrition, mineral particle size.

\section{EAcknowledgements}

The authors thank CAPES for the grant provided to the first author.

\footnotetext{
* Part of the Ph.D. thesis of the first author presented in the Post-Graduation Program in Animal Science of the School of Veterinary Medicine and Animal Science, UNESP, Botucatu, Brazil
}

Submitted: August/2010

Approved: December/2010

\begin{abstract}
A total of 405 23-week-old ISA ${ }^{\circledR}$ Brown layers were distributed in a completely randomized experimental design in a factorial arrangement with nine treatments consisting of three dietary calcium levels (3.5, 3.75 , and $4.5 \%)$ and three limestone particle sizes (100\% fine limestone (FL), 70\% FL + 30\% coarse limestone $(\mathrm{CL})$ and $50 \%(\mathrm{FL})+$ $50 \%(C L))$, with nine replicates of five birds per cage. The following parameters were evaluated: percentage of lay, defective eggs, egg weight, egg mass, feed intake, feed conversion ratio (per kg eggs and per dozen eggs), and mortality. Dietary Ca levels significantly affected lay, with birds fed diets containing $4.5 \%$ calcium producing less eggs as compared to those fed 3.0 and $3.75 \%$ Ca. Egg production linearly decreased as dietary Ca levels increased, but blood Ca levels (mg/L) increased in 28-week-old birds. The interaction of dietary Ca levels and limestone particle sizes resulted in a reduction in tibial ash Ca content as dietary $\mathrm{Ca}$ levels increased and as fine limestone was replaced by coarse limestone. It is concluded that a dietary Ca level of $3.75 \%$ and $100 \%$ fine particle limestone are required to maintain adequate egg production and available Ca blood level.
\end{abstract}

\section{INTRODUCTION}

Calcium is the mineral with the highest concentration in the body of poultry, consisting of $1.5 \%$ of its body weight. It is more than one third of total mineral body content of an adult bird (Klasing, 1998) and represents one third of eggshell components.

During lay, structural bone loss (medullary and cortical) and the subsequent development of osteoporosis are associated to the medullary bone. Medullary bones in females are shaped in response to estrogen. The role of these bones in mineral homestasis is more important than their structural skeletal function, and it is associated to bone mineralization and eggshell formation. Studies on layer skeleton using fluorochrome (Cransberg et al., 2001) showed that there is no formation of medullary or cortical bone during eggshell formation; only the shape of medullary bones are changed. However, the high mobilization of minerals for eggshell deposition may result in osteoporosis and consequently, in bone fragility.

Calcium has an essential role in nutrition and calcium turnover determines the optimal calcium level for bone formation, including the tíbia, but the relationship between calcium turnover and the development of osteoporosis is still not clear (Cransberg et al., 2001). The initial calcium reserves when chickens are in lay may be compromised if the diet is not correctly balanced, with consequent influence on egg 
Pelicia K, Mourao JLM, Garcia EA, Pinheiro VMC, Berto DA, Molino AB, Faitarone ABG, Vercese F, Santos GC, Silva AP
Effects of Dietary Calcium Levels and Limestone Particicle Size on The Performance, Tibia and Blood of Laying Hens production. Unbalanced diets may deeply influence the capacity of hens maintaining bone integrity during lay, as bones may be required to supply calcium for egg production and body maintenance, particularly when hens are still growing.

Calcium availability in dietary calcium sources present great variability as a function of their chemical composition and their capacity to physical bind to other dietary components, forming compounds that present low solubility and availability (Mcnaughton \& Deaton, 1981). Sá et al. (2004) determined 99\% relative calcium availability in dicalcium phosphate, $84 \%$ in calcitic limestone, and $75 \%$ in dolomitic limestone. According to the NRC (1994), calcium bioavailability in dolomitic limestone ranges between 50 and $75 \%$, whereas it is close to $90 \%$ in calcitic limestone. This is due to the fact that calcitic limestone has crystals with alternate layers of calcium and carbonate ions (calcite), while in dolomitic limestone, magnesium partially replaces calcium, resulting in denser and less soluble crystals. In addition, magnesium is also a calcium antagonist, influencing calcium intestinal absorption. Thus, the higher complexity of dolomitic limestone makes its calcium less available as compared to calcitic limestone (Ross et al., 1984). Moreover, Bessa (1992) concluded that the feeding of calcium sources that contain phosphorus in their molecule results in lower bone ash content relative to exclusive calcium sources, possibly to their lower calcium bioavailability to poultry.

The study of different calcium levels fed at different combinations of particle size is essential in layers, as both these factors influence bone calcium content. Calcium is essential to maintain bone structure, and bone fragility, particularly of the tibia, may cause death. The amount of tibial calcium mobilization can be used to determine if the diet is supplying calcium requirements for egg production and body maintenance.

The present experiment aimed at studying the effect of dietary calcium levels and limestone particle size composition on performance parameters, calcium absorption, and tibial calcium content of commercial layers in the beginning of the first laying cycle.

\section{MATERIAL AND METHODS}

The experiment was carried out at the poultry science research center of the University of Trás-osMontes and Alto Douro (UTAD), Vila Real, Portugal.

In this trial, $405 \mathrm{Isa}{ }^{\circledR}$ Brown layers with 23 weeks of age at the onset of the first laying cycle were used, and submitted to a photoperiod of 16 hours of light per day.

Birds were distributed in a completely randomized experimental design in a factorial arrangement with nine treatments, consisting of three dietary calcium levels (3.0, 3.75, and 4.5\%) and three limestone particle size compositions. The following treatments were applied: $3.0 \%$ calcium with 100\% fine limestone (T1); $3.0 \%$ calcium with $70 \%$ fine limestone and $30 \%$ coarse limestone (T2); 3.0\% calcium with $50 \%$ fine limestone and 50\% coarse limestone (T3); 3.75\% calcium with $100 \%$ fine limestone (T4); $3.75 \%$ calcium with $70 \%$ fine limestone and $30 \%$ coarse lime (T5); $3.75 \%$ calcium with 50\% fine limestone and $50 \%$ coarse limestone (T6); $4.5 \%$ calcium $100 \%$ fine limestone (T7); $4.5 \%$ calcium with $70 \%$ fine limestone and $30 \%$ coarse limestone (T8); $4.5 \%$ calcium with 50\% fine limestone and 50\% coarse limestone (T9).

Diets were formulated according to the NRC (1994) requirements specific for the genetic line and contained equal energy and protein levels.

Limestone in-vitro solubility was determined according to the method described by Cheng \& Coon (1990) of the University of Minnesota (weight loss percentage method).

Eggshell percentage was determined by drying the eggshell in an oven for three days at $60^{\circ} \mathrm{C}$ and letting return to room temperature before weighing, and calculated by dividing the obtained weight by egg weight.

Eggshell thickness was determined in the same samples used to calculate eggshell percentage in each treatment. Thickness was measured with a pachymeter in three different points in the equatorial region of the egg, and the average was calculated.

Egg specific weight was calculated by immersing intact eggs collected at the end of each period in solutions with density ranging between 1,060 and $1,100 \mathrm{~g} / \mathrm{cm}^{3}$ in 0,005 gradients. The solutions were prepared as recommended by Moreng \& Avens (1990).

Eggshell weight per surface area (ESWSA) was expressed in $\mathrm{mg} / \mathrm{cm}^{2}$, according to Abdallah et al. (1993), applying the following equation: ESWSA = $\{E G W /[3.9782 \times(E W 0.7056)]\} \times 1000$, where: $E S W=$ eggshell weight, and $\mathrm{EW}=$ egg weight.

Albumen percentage was determined by dividing albumen weight by egg weight and multiplying the result per 100 .

Albumen height was determined using a micrometer.

Eggs were weighed in a scale with $0.01 \mathrm{~g}$ precision. 
Pelicia K, Mourao JLM, Garcia EA, Pinheiro VMC, Berto DA, Molino AB, Faitarone ABG, Vercese F, Santos GC, Silva AP

Effects of Dietary Calcium Levels and Limestone Particicle Size on The Performance, Tibia and Blood of Laying Hens

A total of $2.0 \mathrm{~mL}$ of blood was collected from

Table 1 - Ingredients and calculated composition of the experimental diets fed to layers between 23 and 35 weeks of age.

\begin{tabular}{|l|c|c|c|}
\hline \multirow{2}{*}{ Ingredients (\%) } & \multicolumn{3}{|c|}{ Tratamentos } \\
\cline { 2 - 4 } & T1-3 & T4-6 & T7-9 \\
\hline Corn & 58.30 & 58.30 & 58.30 \\
\hline Soybean meal & 17.66 & 17.66 & 17.66 \\
\hline By-products of wheat fermentation & 4.83 & 4.83 & 4.83 \\
\hline Sunflower meal & 1.93 & 1.93 & 1.93 \\
\hline Wheat midds & 1.54 & 1.54 & 1.54 \\
\hline Poultry fat & 0.97 & 0.97 & 0.97 \\
\hline Sugarcane molasses & 0.97 & 0.97 & 0.97 \\
\hline Monocalcium phosphate (0.66) & 0.97 & 0.97 & 0.97 \\
\hline Sodium chloride & 0.25 & 0.25 & 0.25 \\
\hline Corn germen & 0.12 & 0.12 & 0.12 \\
\hline Mineral and vitamin supplement & 1.08 & 1.08 & 1.08 \\
\hline Calcium carbonate & 5.48 & 7.45 & 9.42 \\
\hline Sand & 5.90 & 3.93 & 1.96 \\
\hline Calculated composition & & & \\
\hline Calcium (\% diet) & 3.00 & 3.75 & 4.50 \\
\hline Phosphorus (\% diey) & 0.32 & 0.32 & 0.32 \\
\hline Metabolizable energy (kcal/kg) & 2703 & 2703 & 2703 \\
\hline Protein (\% diet) & 15.26 & 15.35 & 15.35 \\
\hline Crude fiber (\%) & 3.1 & 3.1 & 3.1 \\
\hline Methionine (\% dieta) & 0.3 & 0.3 & 0.3 \\
\hline Total Methionine+Cystine (\%) & 0.6 & 0.6 & 0.6 \\
\hline Lysine & 0.7 & 0.7 & 0.7 \\
\hline Sodium & 0.12 & 0.12 & 0.12 \\
\hline Choline & 0.098 & 0.098 & 0.098 \\
\hline Total threonine & 0.62 & 0.62 & 0.62 \\
\hline Total tryptophan & 0.21 & 0.21 & 0.21 \\
\hline Mineral and vitamin supplement per kg feed: vitamin A: 9000 IU; vitamin \\
\hline D3: 2100 IU; vitamin E: 30 mg; nicotinic acid: 30 mg; vitamin B12: 0.12 \\
miboflavin: 4.5 mg; vitamin B6: 2.0 mg; folic acid: 0.5 mg; biotin: 0.5 mg; \\
Fe: 50 mg; Cu: 10 mg; Mn: 70 mg; Zn: 50 mg; Co: 0.2 mg;: 1.0 mg; Se: \\
\hline O.3 mg; BHT: 150 mg; monensin: 100 ppm. & & \\
\hline
\end{tabular}

Haugh units were calculated using the equation suggested by Card \& Nesheim (1968).

$\mathrm{HU}=100 \log \left(\mathrm{H}+7.57-1.7 \mathrm{~W}^{0.37}\right)$ where:

$\mathrm{H}=$ albumen height $(\mathrm{mm})$

$\mathrm{W}=$ egg weight $(\mathrm{g})$

Yolk height was determined in the center of the yolk using a micrometer.

Yolk color was determined using a Minolta Chroma meter CR-200 apparatus. Yolk were submitted to the CIELAB for analysis of luminosity $\left(L^{*}\right)$, redness $\left(a^{*}\right)$, and yellowness $\left(b^{*}\right)$. the brachial vein of one bird per cage at 28 and 35 weeks of age and placed in heparinized tubes. Calcium was determined using an atomic-absorption spectrophotometer, after which blood samples were centrifuged (2500rpm, 15min) to obtain the serum. A volume of $0.5 \mathrm{~mL}$ of serum was diluted in $9.5 \mathrm{~mL}(1: 20)$ strontium solution $(91.277 \mathrm{~g}$ strontium diluted in $1 \mathrm{~L}$ de deionized water (solution at $3 \%)$ ).

At the end of the experiment, nine birds per treatment (one per replicate) were sacrificed to analyze calcium content in the tibia. The left tibia was dissected and frozen at $-20^{\circ} \mathrm{C}$ for subsequent calcium analysis. Bone samples were ground, placed in petroleum ether for $2 \mathrm{~h}$, dried in an oven at $105^{\circ} \mathrm{C}$ for $12 \mathrm{~h}$, and then burnt in a furnace at $550{ }^{\circ} \mathrm{C}$ for $3 \mathrm{~h}$ to obtain the ashes. Ashes were dissolved in concentrated $\mathrm{HCl}$ to determine calcium content in an atomic-absorption spectrophotometer.

The obtained results were submitted to analysis of variance and when statistical difference was detected, a test for comparison of the means was applied. SAS (2000) statistical package was used. Calcium levels and limestone particle size estimates were established using analysis of regression.

\section{RESULTS AND DISCUSSION}

The in-vitro solubility results of different limestone particle sizes, both of which contained $38 \% \mathrm{Ca}$, indicate that solubility is related to particle size. When limestone particle size increased from $0.18 \mathrm{~mm}$ (fine) to $3.90 \mathrm{~mm}$ (coarse), in-vitro solubility was reduced from 25.56 to $22.37 \%$.

\section{Performance parameters}

Table 2 shows that there was no influence $(p<0.05)$ of $\mathrm{Ca}$ levels or limestone particle size composition on defective eggs, egg weight, egg mass, feed intake, feed conversion ratio per dozen eggs, feed conversion ratio per kg eggs, or layer livability, which was $99 \%$. The feed intake results are consistent with other studies (Maclntryre et al., 1963; Harms \& Waldroup, 1971), which did not find any adverse effect on feed intake when calcium consumption increased from 8.9 to $9.5 \mathrm{~g} / \mathrm{bird} / \mathrm{day}$.

Egg production was affected by the treatments $(p<0.001)$. Daily calcium intake increased as dietary Ca level increased, and ranged between 4 and $5.2 \mathrm{~g}$ (Figure 2). The results showed that $4 \mathrm{~g} /$ day of calcium intake increased egg production, whereas Cheng \& Coon 
Table $\mathbf{2}$ - Performance of layers fed different Ca levels and different limestone particle sizes.

\begin{tabular}{|c|c|c|c|c|c|c|c|c|}
\hline & \multirow[t]{2}{*}{$\begin{array}{l}\text { Lay } \\
(\%)\end{array}$} & \multirow[t]{2}{*}{$\begin{array}{c}\text { Def.eggs }{ }^{1} \\
(\%)\end{array}$} & \multirow[t]{2}{*}{$\begin{array}{c}\text { Egg weight } \\
\text { (g) }\end{array}$} & \multirow[t]{2}{*}{$\begin{array}{l}\text { Egg mass } \\
(\mathrm{g} / \mathrm{d})\end{array}$} & \multirow[t]{2}{*}{$\begin{array}{c}\text { Feed intake } \\
(\mathrm{g} / \mathrm{d})\end{array}$} & \multirow[t]{2}{*}{$\begin{array}{c}\text { Ca intake } \\
(\mathrm{g} / \mathrm{d})\end{array}$} & \multicolumn{2}{|c|}{$\begin{array}{c}\text { Feed conversion } \\
\text { ratio }\end{array}$} \\
\hline & & & & & & & dozen & kg \\
\hline \multicolumn{9}{|l|}{ Ca level (\%) } \\
\hline 3.0 & 91.3 & 0.2 & 63.2 & 57.7 & 132.6 & 3.98 & 1.744 & 2.314 \\
\hline 3.75 & 90.6 & 0.3 & 63.5 & 57.5 & 133.4 & 5.00 & 1.769 & 2.335 \\
\hline 4.5 & 87.6 & 0.7 & 64.1 & 56.2 & 130.2 & 5.21 & 1.775 & 2.319 \\
\hline \multicolumn{9}{|l|}{ Particle size } \\
\hline 100FL & 89.9 & 0.4 & 63.5 & 57.4 & 132.9 & 4.76 & 1.775 & 2.318 \\
\hline 70FL & 90.4 & 0.3 & 63.4 & 57.2 & 131.5 & 4.71 & 1.754 & 2.314 \\
\hline 50FL & 89.2 & 0.6 & 63.6 & 56.8 & 131.7 & 4.73 & 1.768 & 2.335 \\
\hline \multicolumn{9}{|l|}{ Probability } \\
\hline Ca level & $\mathrm{p}<0.001$ * & NS & NS & NS & NS & $p<0.001$ * & NS & NS \\
\hline Particle size & NS & NS & NS & NS & NS & NS & NS & NS \\
\hline Ca level* particle size & NS & NS & NS & NS & NS & NS & NS & NS \\
\hline CV (\%) & 3.2 & 304.2 & 3.5 & 4.4 & 6.6 & 6.57 & 7.5 & 8.9 \\
\hline
\end{tabular}

(1990) did not observe any effect on egg production when $\mathrm{Ca}$ intake of commercial layers ranged between 2.0 and $4.5 \mathrm{~g} /$ day. In the present experiment, diets containing $4.5 \%$ Ca resulted in a Ca intake of $5.9 \mathrm{~g} /$ day and reduced egg production. This is consistent with the review article of Roland (1986), who found that additional Ca may adversely affect feed intake and egg production due to the excessive levels of $\mathrm{Ca}$ and other minerals, such as magnesium, present in $\mathrm{Ca}$ sources, as well as that excessive $\mathrm{Ca}$ added to the diet is not absorbed by the digestive tract.

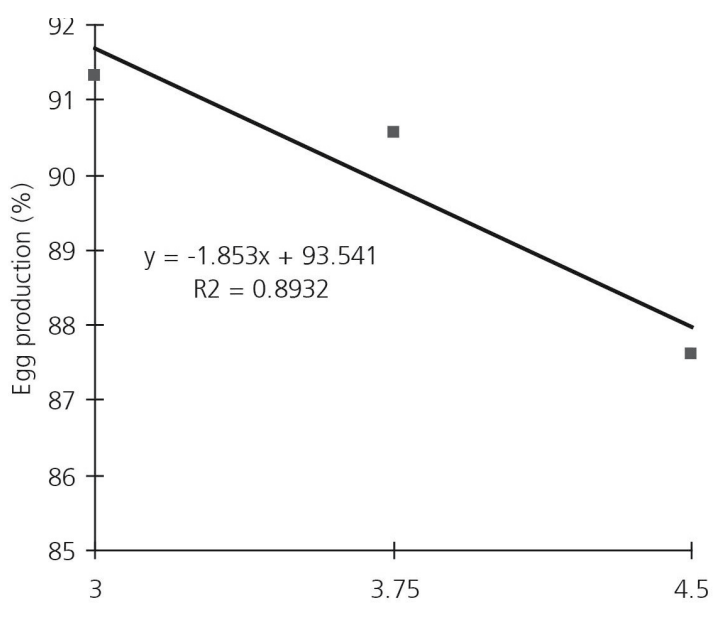

Dietary calcium level

Figure 1 - Effect of dietary calcium level on egg production.

Layers fed diets with 4.5\% Ca presented lower egg production than those fed 3.0 and $3.75 \% \mathrm{Ca}$, with a significant linear reduction of egg production as dietary Ca levels increased (Figure 1). However, egg production was not influenced by limestone particle size. Pizzolante et al. (2006), working with 3.5 and $4.2 \%$ Ca levels and limestone with 100\%, 70\%, and $50 \%$ fine particles, did not observe any effect on egg production, egg loss, egg weight, egg mass, feed intake or feed conversion ratio. Faria (2002) did not observe any effect of limestone particle size on egg production. The feed intake results obtained in the present study agree with those of Fraga (1994), who observed that the supply of feeds with more than $4 \%$ $\mathrm{Ca}$ to layers may reduce feed palatability and interfere in feed intake.

Table 2 shows that the high feed intake level caused excessive $\mathrm{Ca}$ intake, particularly in birds fed diets with high Ca levels, resulting in low Ca utilization. In order to maintain adequate blood $\mathrm{Ca}$ levels, birds lost $\mathrm{Ca}$ in the feces, and mobilized bone $\mathrm{Ca}$, with consequent numerical reduction in tibial $\mathrm{Ca}$ content as dietary Ca increased (Table 3). Despite not being statistically significant due to the high coefficient of variation, this also caused a numerical increase in the rate of defective eggs and significantly reduced the percentage of lay.

Figure 2 shows the significant linear increase $(p<0.001)$ in Ca intake as dietary Ca level increased.

In the period of 28 weeks, blood Ca level increased as a function of the increase in dietary Ca level (Figure 3). In addition, blood Ca level numerically decreased as the ratio of coarse limestone increased; however, this result was not statistically significant due to the 
high coefficient of variation (Table 3). This is possibly due to the fact the metabolism rate of young layers (28 weeks of age) is high, and therefore they present better absorption of more soluble limestone sources (fine particles) that supply more available $\mathrm{Ca}$, as well as to the intake of the diet with higher Ca levels.

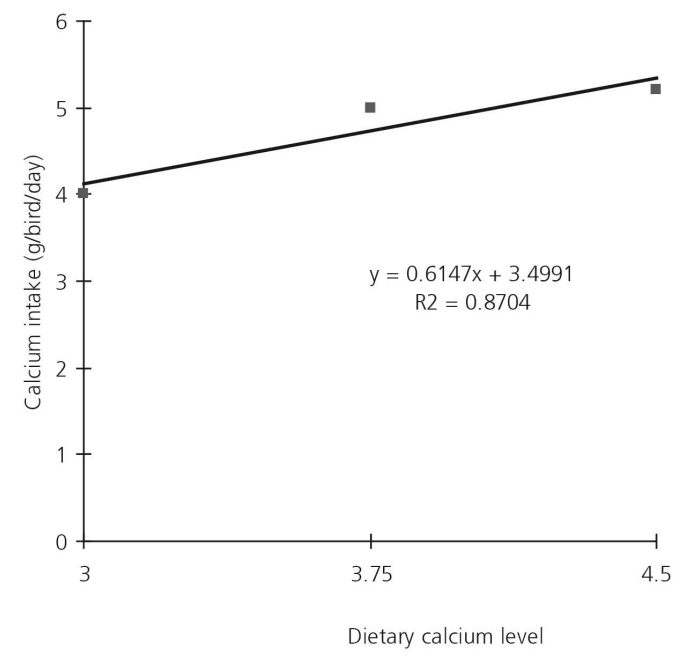

Figure 2 - Effect of calcium level on calcium intake by layers.

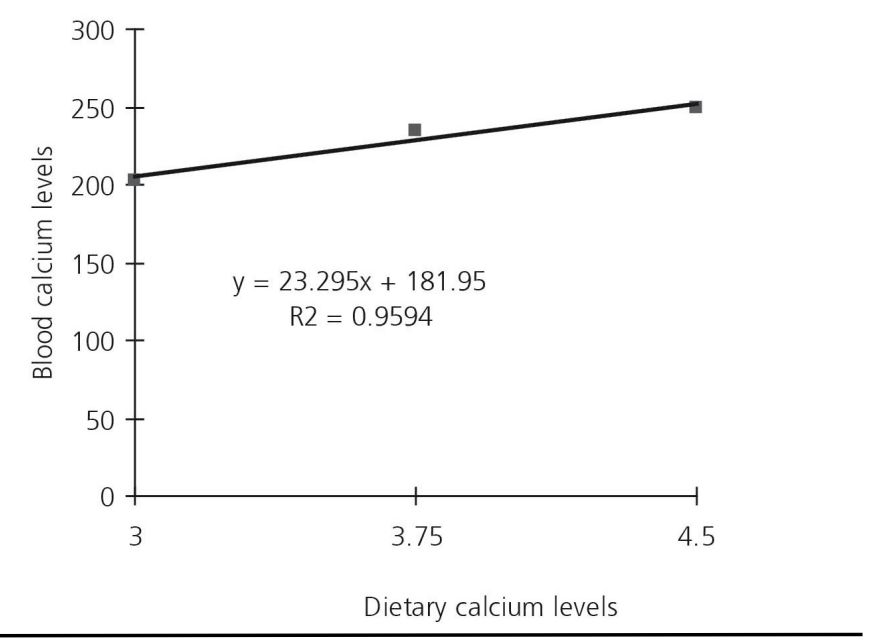

Figure 3 - Effect of dietary Ca levels on blood Ca levels in 28-weekold layers.

At the end of the experiment, when birds were 35 weeks of age, there was saturation due to the continuous supply of high Ca levels, resulting in a reduction of tibial ash $\mathrm{Ca}$ content to maintain adequate blood Ca levels when excessive Ca was supplied (Roland, 1986). However, as these birds were older, their $\mathrm{Ca}$ metabolization process is longer, and therefore coarse limestone is preferred as it provides Ca continuously, and, together with the numerical reduction in $\mathrm{Ca}$ intake, as shown in Table 2, it promotes a numerical increased in blood Ca levels (Table 3). Tables 2 and 3 do not show any statistical difference $(p<0.05)$ due to high coefficient of variation obtained of $\mathrm{Ca}$ intake and blood $\mathrm{Ca}$ levels when diets with coarse limestone were supplied.

\begin{tabular}{|c|c|c|c|c|}
\hline & \multicolumn{2}{|c|}{$\begin{array}{l}\text { Blood calcium level } \\
\text { (mg/L) }\end{array}$} & \multicolumn{2}{|c|}{$\begin{array}{l}\text { Calcium (\%) } \\
\text { at } 35 \text { weeks }\end{array}$} \\
\hline & 28 weeks & 35 weeks & Tibia & Tibial ashes \\
\hline \multicolumn{5}{|l|}{ Ca levels (\%) } \\
\hline 3.0 & 202 & 228 & 0.171 & 0.353 \\
\hline 3.75 & 233 & 215 & 0.171 & 0.349 \\
\hline 4.5 & 253 & 227 & 0.168 & 0.341 \\
\hline \multicolumn{5}{|c|}{ Limestone particle size } \\
\hline $100 \mathrm{FL}$ & 242 & 218 & 0.168 & 0.343 \\
\hline $70 \mathrm{FL}$ & 216 & 222 & 0.171 & 0.347 \\
\hline $50 \mathrm{FL}$ & 229 & 231 & 0.173 & 0.352 \\
\hline \multicolumn{5}{|l|}{ Probability } \\
\hline Ca level & $p<0.05^{*}$ & NS & NS & NS \\
\hline Particle size & NS & NS & NS & NS \\
\hline $\begin{array}{l}\text { Ca level* } \\
\text { particle size }\end{array}$ & NS & NS & NS & $p<0.001$ * \\
\hline$C V(\%)$ & 31.3 & 15.6 & 6.6 & 6.3 \\
\hline
\end{tabular}

Those results are also evidenced by the findings in tibial ash, where the effect caused by saturation with increased dietary Ca levels required Ca mobilization from the tibia, as shown by the numerical reduction of tibial ash $\mathrm{Ca}$ content. The increase in dietary $\mathrm{Ca}$ promoted lower tibial Ca mobilization when coarse limestone was used (Table 3).

Figure 4 presents the interaction between dietary $\mathrm{Ca}$ levels and limestone particle size on tibial ash $\mathrm{Ca}$ content in 35-week-old layers, showing that when $\mathrm{Ca}$ levels and coarse limestone particles increased, Ca tibial ash decreased. This is probably caused by excessive Ca availability (Roland, 1986), resulting in lower Ca intestinal absorption and tibial Ca mobilization.

Jardim Filho et al., (2005) also found negative effects on tibial $\mathrm{Ca}$ content when working with different $\mathrm{Ca}$ sources: Source 1 (fine limestone, $36.43 \% \mathrm{Ca}, 80.68 \%$ solubility); Source 1 (intermediate limestone, $34.29 \%$ Ca, 75.72\% solubility); Source 1 (coarse limestone, $34.29 \% \mathrm{Ca}, 59.02 \%$ solubility); Source 2 (fine limestone, $35.36 \%$ Ca, $75.21 \%$ solubility); Source 2 
(coarse limestone, 35\% Ca, 65.61\% solubility); Source 3 (coarse limestone, $36.43 \%$ Ca, $72.79 \%$ solubility). Those authors obtained higher $\mathrm{Ca}$ deposition in the tibia in birds fed coarse limestone from Source 1 and fine limestone from Source 2 at 53 and 61 weeks of age, respectively. In 41-week-old birds, tibial Ca content was higher in birds fed coarse limestone from Source 3. These results show that limestone particle size influenced the tibial composition of birds and that Ca source has an important role in Ca supply due to their different $\mathrm{Ca}$ levels and solubility. However, it must also be considered that bird age will determine their higher or lower capacity in balancing this mineral and in their body.

The capacity of the birds of balancing determined nutrients in the body (Dukes, 1996), suggests that other factors, such as genetics and the individual capacity may influence Ca metabolization. Therefore, several factors need to be taken into account, such as health status, opening a wide range of opportunities for future studies, and which may have influenced the contradictory results obtained in the present study.

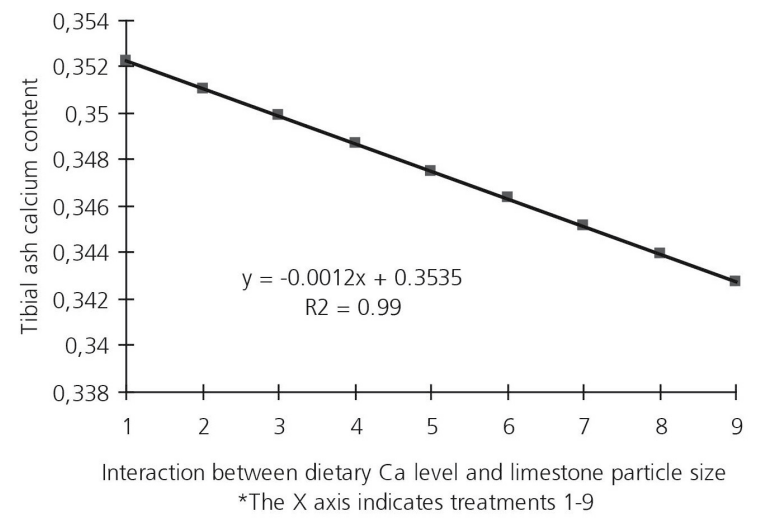

Figure 4 - Effect of dietary Ca levels and limestone particle size on tibial ash Ca content.

\section{CONCLUSIONS}

Based on the results obtained under the conditions of the present study it is concluded that a dietary Ca level of $3.75 \%$ and $100 \%$ fine particle limestone are required to maintain adequate egg production and available Ca blood level. The use of coarse limestone did not influence the evaluated parameters.

\section{REFERENCES}

Bessa LHF. Biodisponibilidade de cálcio em suplementos de cálcio e fósforo para aves [issertação]. Belo Horizonte (MG): Universidade federal de Minas Gerais; 1992.
Cheng TK, Coon CN. Effect of calcium source, particle size, limestone solubity in vitro, and calcium intake level on layer bone status and performance. Poultry Science 1990; 69:2214-2219.

Cransberg PH, Parkinson GB, Wilson S, Thorp BH. Sequential studies of skeletal calcium reserves and structural bone volume in a commercial layer flock. British Poultry Science 2001; 42:260-265.

Swenson MJ, Reece WO. Dukes: fisiologia dos animais domésticos. 11.ed. Rio de Janeiro: Guanabara Koogan; 1996.

Faria LV. Granulometria do calcário calcítico e níveis de cálcio para poedeiras comerciais em segundo ciclo de reprodução [dissertação]. Lavras (MG): Universidade Federal de Lavras; 2002.

Fraga MJ, Alimentacion mineral y vitamínica de la gallina ponedora. In: Blas C, Mateos GG. Nutrición y alimentación e gallinas ponedoras. Madrid: Ministério de Agricultura, Pesca y Alimentación, Mundi Prensa e Editorial Aedos; 1994. p.161-185.

Harmz RH, Waldroup PW. The effect of high dietary calcium on the performance of laying hens. Poultry Science 1971; 50:967- 969.

Jardim Filho RM, Stringhini JH, Café MB, Andrade MA, Sakamoto MI, Franco JRG. Influência das fontes e granulometria do calcário calcítico sobre a densidade, resistência e composição mineral da tíbia de poedeiras comerciais. Acta Scientiarum, Animal Sciences 2005; $27(1): 23-28$.

McIntyre TM, Chancey HWR, Gardiner EE. Effect of dietary energy and calcium level on egg production and egg quality. Canadian Journal of Animal Science 1963; 43:337-343.

McNaughton JL, Deaton. Effect of calcium source and particle on calcium utilization [abstracts]. Poltry Science 1981; 59(supl 7): 1568.

National Research Council - NRC. Nutrient requirements of poultry. 9th ed. Washington: National Academy is Sciences; 1994.

Pizzolante CC, Garcia EA, Laganá C, Saldanha ESPB, Deodato AP, Faitarone $A B G$, Scherer MR, Batista L. Effect of the calcium level and limestone particle size on the performance of semi-heavy layers in the second cycle of egg production. Revista Brasileira de Ciência Avícola 2006; 8(3):173-176.

Klasing KC. Amino acid. In: Klasing KC, editor. Comparative avian nutrition. Wallingford: CAB International; 1998. p. 133-170

Roland DA. Sr. Eggshell quality III: Calcium and phosphorus requirements of commercial leghorns. World's Poultry Science Journal 1986; 42:154-165.

Ross RD, Cromwell GL, Stahly TS. Effects of source and the particle size on the biological availability of calcium in calciumsupplements for growing pigs. Journal Animal Science 1984; 59:125-134.

Sá LM, Gomes PC, Albino LFT, Rostagno HS, D'Agostini P. Exigências Nutricionais de Cálcio e sua Biodisponibilidade em alguns alimentos parafrangos de corte no período de 1 a 21 dias de idade. Revista da Sociedade Brasileira de Zootecnia 2004; 33(1): 157-168.

Statistical Analyses System - SAS. User's guide [cd rom]. Cary; 2000. 